\title{
Sound Bites
}

EIKE MARK RINKE

University of Mannheim, Germany

A sound bite is an authentic mediated representation of an uninterrupted segment of audible speech. It originates from radio but can occur in any medium possessing a sound component. The term "sound bite" refers to the origins of political sloganeering techniques and is intertwined with historical developments in the contexts, techniques, and routines of auditory and audiovisual journalistic production (Jamieson, 1988). The term "image bite" is its visual analogue, best conceived as an authentic mediated representation of an uninterrupted segment of visible speech that can occur in any medium possessing a visual component. An image bite can also occur when the person shown speaking is not also heard. It may, for example, be used to accompany the voice-over narration of a reporter (Grabe \& Bucy, 2009).

While both terms have sometimes been defined more loosely in past studies, they provide the most analytical power if used to clearly distinguish between auditory and visual representations of political speech. From these definitions derive three logical possibilities of how a speaker may be directly represented in audiovisual media: A speaker may be heard but not shown (sound bite only), they may be not heard but shown (image bite only), and they may be both heard and shown (sound/image bite combination).

Sound bites matter because they are an essential component of news discourse and, as a consequence, relevant to the formation of individual and public opinion. They are also indicative of changes in journalistic practices and an important component of material news culture (Esser, 2008).

The use of sound bites in news products has raised concerns among journalism scholars and the general public. First, some have argued that the use of sound bites has given rise to public relations advisors, pollsters, and media consultants who devise spin tactics for communications in sound-bite format (Slayden \& Whillock, 1999). Second, the use of highly edited sound bites has prompted concerns that journalists and editors may exert excessive influence over the news product and impose their views on audiences (Steele \& Barnhurst, 1996). Third, commentators have been concerned about possible partisan biases in how sound bites are allocated among and reflect back on competing political candidates and parties (Grabe \& Bucy, 2009). Fourth, scholars have worried that sound bites may fragment the news product and prevent a substance-focused framing of issues (Farnsworth \& Lichter, 2011).

Traditional sound-bite research has focused on tallying the average length of candidate sound bites across election campaigns. Early studies garnered attention when they found that the average candidate sound bite in TV news about election campaigns had shrunk from 43 seconds in 1968 to about 9 seconds in 1992 in the United States

The International Encyclopedia of Journalism Studies. Tim P. Vos and Folker Hanusch (General Editors), Dimitra Dimitrakopoulou, Margaretha Geertsema-Sligh and Annika Sehl (Associate Editors).

(C) 2019 John Wiley \& Sons, Inc. Published 2019 by John Wiley \& Sons, Inc.

DOI: $10.1002 / 9781118841570$. iejs0271 
(Hallin, 1992), a level at which it has stabilized since (Farnsworth \& Lichter, 2011). Shrunk sound bite sizes in television newscasts have been one of the most replicable findings across other countries, including Australia, France, Germany, and the United Kingdom.

More recent sound-bite research has investigated the causes and consequences of both the length and content of sound bites. Research on the factors influencing sound bites has shown that while commercial media systems and newsrooms still prefer shorter sound bites, public-service media systems and news organizations have drawn near these lower levels. Different national media and political systems produce different sound-bite content during election campaigns. For example, candidate sound bites in the United States are heavy on attack rhetoric while British candidates are often shown defending themselves, and German and French candidates are often featured discussing campaign developments (Esser, 2008).

Less is known about the consequences of sound bites. Early studies found that the mere presence of "authentic" candidate sound and image bites enhanced the impression they made on voters while the length of sound bites was unrelated to it (Donsbach \& Jandura, 2003). More recent work demonstrated that the long-untested assumption that sound bites diminish the substance of news coverage holds true: shorter sound bites produce a news discourse in which speakers are lacking the time to justify their views (Rinke, 2016). Sound-bite practices may also disadvantage certain groups: for example, when journalists deploy sound bites of female candidates in order to emphasize counter-stereotypical behavior this can lead to a disproportionate focus on aggressive behaviors in their sound bites (Gidengil \& Everitt, 2000). Recent research on sound bites has aimed to provide rigorous empirical assessments of their normative implications. Implicit in much of it is a critique of news production processes driven by market-driven models of journalism that favor the use of ever-shorter, dramatic sound bites.

Sound-bite research is bound to develop as media technology and journalism models evolve. In the digital age, the mediation of political speech is taking on new forms with online media that are increasingly rich in audio and audiovisual content. Sound bites are thus bound to remain an important part of news products and culture. Given their discursive implications, future sound-bite research should track these developments and expand empirical inquiry to new social contexts and media platforms.

SEE ALSO: Broadcast Journalism: Television; Commodification of News; Interpretive Journalism; News Production Routines; Political Coverage; Public Sphere; Reporting and Interviewing; Social Construction of News

\section{References}

Donsbach, W., \& Jandura, O. (2003). Chances and effects of authenticity: Candidates of the German federal election in TV news. International Journal of Press/Politics, 8(1), 49-65. doi:10.1177/1081180X02238784 
Esser, F. (2008). Dimensions of political news cultures: Sound bite and image bite news in France, Germany, Great Britain, and the United States. International Journal of Press/Politics, 13(4), 401-428. doi:10.1177/1940161208323691

Farnsworth, S. J., \& Lichter, S. R. (2011). The nightly news nightmare: Television's coverage of U.S. presidential elections, 1988-2008 (3rd ed.). Lanham, MD: Rowman \& Littlefield.

Gidengil, E., \& Everitt, J. (2000). Filtering the female: Television news coverage of the 1993 Canadian leaders' debates. Women \& Politics, 21(4), 105-131. doi:10.1300/J014v21n04_04

Grabe, M. E., \& Bucy, E. P. (2009). Image bite politics: News and the visual framing of elections. New York, NY: Oxford University Press.

Hallin, D. C. (1992). Sound bite news: Television coverage of elections, 1968-1988. Journal of Communication, 42(2), 5-24. doi:10.1111/j.1460-2466.1992.tb00775.x

Jamieson, K. H. (1988). Eloquence in an electronic age: The transformation of political speechmaking. New York, NY: Oxford University Press.

Rinke, E. M. (2016). The impact of sound-bite journalism on public argument. Journal of Communication, 66(4), 625-645. doi:10.1111/jcom.12246

Slayden, D., \& Whillock, R. K. (Eds.). (1999). Soundbite culture: The death of discourse in a wired world. Thousand Oaks, CA: SAGE.

Steele, C. A., \& Barnhurst, K. G. (1996). The journalism of opinion: Network news coverage of U.S. presidential campaigns, 1968-1988. Critical Studies in Mass Communication, 13(3), 187-209. doi:10.1080/15295039609366975

\section{Further reading}

Salgado, S., \& Strömbäck, J. (2012). Interpretive journalism: A review of concepts, operationalizations and key findings. Journalism, 13(2), 144-161. doi:10.1177/1464884911427797

Strömbäck, J., \& Dimitrova, D. V. (2011). Mediatization and media interventionism: A comparative analysis of Sweden and the United States. International Journal of Press/Politics, 16(1), 30-49. doi:10.1177/1940161210379504

Eike Mark Rinke is a postdoctoral research associate in the Centre for European Social Research (MZES) at the University of Mannheim, Germany. His scholarship on journalism, news cultures, and mediated deliberation has been published in the Journal of Communication, Political Communication, and the International Journal of Communication. Rinke received the 2015 Gene Burd Outstanding Dissertation Award from the Journalism Studies Division, the 2017 Outstanding Dissertation in Political Communication Award from the Political Communication Division of the International Communication Association (ICA), and Junior Scholar Awards from the American Association for Public Opinion Research (AAPOR, 2016) and the Political Psychology Section of the American Political Science Association (APSA, 2015).

He is past editor of the Political Communication Report, the newsletter of the Political Communication Divisions of the ICA and APSA. 